\title{
Pengukuran Konsep Amanah dalam Pendekatan Kualitatif dan Kuantitatif
}

\author{
Ivan Muhammad Agung1, Desma Husni
}

Fakultas Psikologi UIN Sultan Syarif Kasim Riau

\begin{abstract}
Amanah is the basic foundation of human social relations. This study consisted of two studies, study 1 aims to find the concept of amanah in using the prototype methodology with total number of 444 participants and study 2 aims to create a new of measuring amanah based on findings of study 1 with total number of 201 participants. The results of study 1 showed that the amanah is a person who have a positive character (trusteed, responsibility, honesty) and do task. While the results of study 2 showed that the scale of the amanah has a high reliability consists of three factors, namely integrity, do the task and benevolence. The implications of the research discussed in psychological measurement and islam
\end{abstract}

Keywords: amanah, measurement, trust, trustworthiness

Abstrak. Amanah merupakan fondasi dasar dalam relasi sosial manusia. Penelitian ini terdiri dari dua studi. Studi 1 bertujuan untuk menemukan konsep amanah menggunakan prototipe metodologi dengan jumlah partisipan sebanyak 444 partisipan, dan pada studi 2 bertujuan untuk membuat alat ukur amanah berdasarkan hasil studi 1 dengan jumlah partisipan sebanyak 201 partisipan. Hasil penelitian studi 1 menunjukkan bahwa orang amanah adalah orang yang memiliki karakter positif (dapat dipercaya, bertanggung jawab, jujur) dan melaksanakan tugas. Sementara hasil studi 2 menunjukkan bahwa amanah memiliki reliabilitas yang baik dan terbentuk atas tiga faktor, yaitu integritas, melaksanakan tugas dan kebajikan. Implikasi penelitian dibahas dalam konteks pengukuran psikologi dan islam.

Kata kunci: amanah, kepercayaan, keterpecayaan, pengukuran

Hubungan interpersonal menjadi topik menarik di penelitian psikologi. Banyak para ahli berusaha mengeksplorasi faktor apa yang menyebabkan kesuksesan dan kegagalan dalam hubungan interpersonal, seperti pemaafan (Allemand, dkk., 2007; McCullough, Worthington \& Rachal, 1997), kepercayaan (Lewicki, Mcallister, \& Bies, 1998), respek (Frei \& Shaver, 2002),

\footnotetext{
${ }^{1}$ Korespondensi isi artikel dapat melalui email: ivan.agung@uin-suska.ac.id
}

komitmen (Wieselquist, dkk., 1999). Salah satu isu penting dalam hubungan interpersonal dalam konteks masyarakat Indonesia adalah amanah. Amanah memiliki peran penting dalam relasi interpersonal individu. Sikap dan perilaku amanah mampu membentuk hubungan positif antar individu dan kelompok. Menurut Hamka (1990) amanah merupakan pondasi dasar dalam kehidupan bermasyarakat dan bernegara. Amanah merupakan perekat sosial dalam membangun solidaritas di 
masyarakat yang bertujuan membentuk kerja sama sesama individu (Pulungan, 2006). Tanpa amanah kehidupan masyarakat dan bernegara menjadi rusak. Misalkan, banyak perilaku kriminal atau konflik diakibatkan karena tidak amanah dalam menjalankan tugas dan berperilaku.

Definisi amanah sangat luas cakupannya. Amanah meliputi segala yang berkaitan hubungan interpersonal antar manusia dan hubungan dengan Sang Penguasa Alam, yaitu Allah. Menurut Ibnu Katsir (2013) amanah adalah semua tugas atau pembebanan agama yang meliputi perkara dunia dan akhirat yang ditujukan kepada manusia. Dari segi bahasa, amanah berasal dari bahasa arab yang berarti aman, jujur, atau dapat dipercaya. Sementara menurut Kamus Besar Bahasa Indonesia (2013) amanah adalah sesuatu yang dititipkan kepada orang lain, setia, dan dapat dipercaya. Amanah merupakan kepercayaan yang diberikan kepada seseorang untuk ditunaikan kepada yang berhak (Amirin, 2007). Orang yang amanah adalah orang yang dapat menjalankan tugas yang diberikan.

Dalam perspektif islam (Al-Qur'an dan Hadis), amanah dapat dilihat dari berbagai dimensi. Di Al-Quran terdapat enam kata amanah, yaitu Al-Qur'an surat Al Ahzab: 72, amanah sebagai tugas atau kewajiban; surat Al Baqorah: 283, amanah sebagai hutang atau janji yang harus ditunaikan; surat An Nisa':58, amanah sebagai tugas yang harus disampaikan pada yang berhak; surat Al Anfal: 27, tentang menjaga amanah; surat AlMukminun: 8, anjuran memelihara amanah; dan surat Al Mangarij: 32 anjuran memelihara amanah. Sementara dalam Hadis, amanah dapat ditemui di beberapa hadis tentang amanah, misalkan, "Setiap dari kalian adalah pemimpin dan setiap dari kalian akan dimintai pertanggungjawaban dari yang dipimpinnya...." (H.R. Muslim). "Apabila seseorang membicarakan sesuatu kepada orang lain (sambil) menoleh ke kiri dan ke kanan (karena yang dibicarakan itu rahasia, maka itulah amanah (yang harus dijaga). (HR. Abu Dawud).

Dari uraian tersebut dapat disimpulkan bahwa amanah meliputi tiga dimensi. Pertama, berkaitan dengan hubungan dengan Allah. Dalam hal ini amanah dilihat lebih luas dan dalam. Amanah diartikan sebagai kewajiban hamba kepada Allah yang harus dilakukan manusia. Kedua, terkait dimensi antar manusia. Dalam hal ini amanah dilihat sebagai karakter terpuji dan tugas yang harus dilaksanakan. Ketiga, diri sendiri. Pada dimensi ini amanah dilihat sebagai sesuatu yang harus dikerjakan untuk kebaikan dirinya. Ketiga dimensi tersebut saling terkait satu sama lain, artinya ketika hanya satu dimensi yang dijalankan, maka amanahnya belum sempurna. Misalkan, ketika individu menunaikan amanahnya kepada Allah seperti menjalankan sholat, tetapi dalam hubungan interpersonal tidak berperilaku amanah, maka dalam perspektif islam individu tersebut belum dikatakan amanah.

Dalam konteks psikologi, amanah dikaitkan dengan kepercayaan (trust) dan keterpecayaan (trustworthiness). Penelitian tentang kepercayaan dan keterpecayaan di psikologi mendapat perhatian luas di kalangan ilmuwan psikologi. Banyak penelitian yang dilakukan dengan berbagai setting, seperti pendidikan (Lee, \& Schallert, 2008), sosial (Miller, \& Rempel, 2004) dan organisasi (e.g Mark, Saunders, \& Thornhill, 2004) dan berbagai tingkatan kepercayaan, seperti kepercayaan interpersonal (Lestari, dkk., 2010; Tanis \& Postmes, 2005) dan kelompok atau institusi (Bohnet, \& Baytelman, 2007). Rousseau dkk., (1998) 
mendefinisikan "Trust is a psychological state comprising the intention to accept vulnerability based upon positive expectations of the intentions or behavior of another". Kepercayaan merupakan bias kognitif dalam mengevaluasi (potensi) objek tertentu (orang atau organisasi) (Yamagishi \& Yamagishi, 1994). Sementara Colquitt dkk., (2007) mengatakan kepercayaan dapat diartikan sebagai keinginan untuk menerima risiko terhadap trustee berdasarkan harapan positif atas aksi yang dimilikinya. Berdasarkan definisi tersebut kepercayaan memiliki dua komponen. Pertama, keinginan untuk menerima segala risiko dan kedua, harapan positif pada trustee.

Kepercayaan dikaitkan juga dengan karakteristik atau sifat kenapa seseorang pantas dipercaya atau disebut dengan keterpecayaan (trusworthiness). Menurut pendapat McKnight dkk., (1998) kepercayaan (trust) dan keterpecayaan (trusworthiness) merupakan istilah yang sinonim jika diskusi dalam konteks karakteristik personal yang menginspirasi munculnya harapan positif. Sementara menurut Mayer, Davis, \& Schoorman (1995) memisahkan antara kepercayaan dan keterpecayaan yang terdiri dari tiga karakteristik (kemampuan, kebajikan dan integritas) yang berperan sebagai anteseden pada variabel kepercayaan. Kenapa orang dipercaya? beberapa penelitian menunjukkan karakteristik personal yang meliputi sifat dan perilaku menjadi dasar kenapa orang dipercaya. Menurut Mayer, dkk., (1995) karakteristik personal meliputi tiga hal, yaitu kemampuan, kebajikan, dan integritas. Demikian juga studi meta analisis Colquitt dkk., (2007) menunjukan bahwa orang dipercaya berdasarkan pada tiga hal, yaitu kemampuan, kebajikan, dan integritas.
Sementara itu, penelitian tentang konsep amanah belum banyak dilakukan di Indonesia. Beberapa penelitian tentang amanah dengan berbagai macam pendekatan, misalnya Rohman (2011) dan Pulungan (2006) melakukan penelitian konsep amanah dengan pendekatan kepustakaan berdasarkan Al-Quran dan hadis. Hasilnya menujukkan bahwa konsep amanah merupakan konsep yang luas cakupannya dan meliputi segala aspek kehidupan, baik dunia maupun akhirat. Suprihatiningrum dan Premono (2012) melakukan penelitian tentang persepsi konsep FAST (Fathonah, Amanah, Sidiq, dan Tabligh) pada guru. Pamuji dan Zulaifah (2008) meneliti tentang sulitnya menjaga amanah pada anggota DPRD DIY Yogyakarta dengan pendekatan kualitatif. Tranajaya (2011) meneliti tentang hubungan amanah dan motivasi dengan etos kerja. Sementara beberapa penelitian dengan menggunakan pendekatan psikologi indigenous, yaitu pemimpin yang amanah (Fitriyani, 2014), orang tua yang amanah (Wahyuni, 2014; Fitri, \& Widyastuti, 2014), dan saudara yang amanah (Munthe \& Widyastuti, 2014).

Pada penelitian ini fokus pada dua hal, yaitu menggali pemahaman masyarakat tentang konsep amanah dan konstruksi instrumen amanah. Pertama, konsep amanah tentunya tidak lepas dari pengaruh sosial dan budaya setempat. Istilah atau kata amanah merupakan istilah islam yang diadaptasi dan digunakan dalam konteks masyarakat Indonesia. Amanah merupakan salah satu karakteristik sifat Nabi Muhammad yang diartikan orang yang dapat dipercaya. Demikian juga yang terjadi di Indonesia, istilah amanah dilekatkan pada orang yang dapat dipercaya. Namun konsep ini belum jelas secara operasional: bagaimana orang yang dikatakan amanah dalam konteks Indonesia. 
Oleh karena itu, perlu memahami seperti apa orang yang amanah dalam konteks masyarakat, khususnya mahasiswa.

Kedua, instrumen amanah yang dibuat berdasarkan teori dan konsep dari islam sudah ada namun hingga saat ini belum ada instrumen amanah yang dikonstrak dari bawah (bottom-up), yaitu dari pengalaman sehari-hari masyarakat. Atas dasar itu, instrumen amanah dalam penelitian ini menggunakan prototype methodology, yaitu merupakan salah satu cara untuk mengkonsep atau mengkonstrak atribut psikologis. Pendekatan prototipe terbukti efektif untuk menggambarkan dan mengkonstrak atribut psikologis seperti yang dilakukan, Frei dan Shaver, (2002); dan Langdon (2007). Estimasi reliabilitas menggunakan konsistensi internal dengan teknik alpha cronbach. Sementara untuk validitas instrumen menggunakan validitas berdasarkan isi, yaitu penelaahan mengenai sejauh mana isi aitem sesuai dengan konstrak yang diukur (Furr, 2011). Dengan cara tersebut diharapkan pengukuran konstrak amanah dapat diidentifikasi secara akurat dan sesuai dengan konteks masyarakat Indonesia.

\section{Metode}

Desain dan Prosedur

Peneltian ini terdiri dari dua studi, yaitu studi 1 bertujuan untuk menentukan definisi atau konsep tentang orang amanah. Pada studi 1 partisipan diminta mengisi angket yang berisi pertanyaan terbuka. Pendekatan yang digunakan adalah pendekatan prototip metodologi, yang bertujuan untuk mengeksplorasi dan menggambarkan orang amanah dalam konteks kehidupan sehari-hari. Prototip metodologi merupakan salah satu pendekatan yang digunakan untuk mengkon- sepsi atau mengkonstruk variabel psikologis, seperti kepribadian dan emosi (Langdon, 2007). Metode ini telah banyak dilakukan oleh beberapa penelitian sebelumnya, seperti Fehr dan Russel (1991) tentang cinta; Frei dan Shaver, (2002) dan Langdon (2007) tentang respek. Sementara pada studi 2 bertujuan untuk membuat skala amanah berdasarkan hasil studi 1 dan melakukan analisis psikometris. Metode analisis data yang dilakukan pada studi 1 adalah kualitatif, sedangkan pada studi 2 menggunakan analisis data kuantitatif.

\section{Partisipan}

Partisipan dalam penelitian ini adalah mahasiswa. Pada studi 1 partisipan berjumlah 444 (laki-laki: 94, wanita: 350). Rentang umur dari 17 sampai 23 tahun (rerata 18,69, SD 1,27). Sementara pada studi 2 berjumlah 201 partisipan (umur 1022 tahun). Pengambilan sampel dilakukan dengan teknik non probability sampling, yaitu pengambil sampel dilakukan secara tidak acak atau sesuai dengan tujuan penelitian.

\section{Pengukuran}

Pada studi 1 alat ukur yang digunakan terdiri satu aitem dengan pertanyaan terbuka. "Menurut Anda orang amanah itu seperti apa?". Partisipan diminta menjawab apapun yang ada dipikirannya mengenai orang amanah yang terdiri dari sifat, perilaku atau karakteristik. Setelah itu dilakukan pengumpulan data jawaban partisipan dan dilakukan koding dan membuat kategori berdasarkan jawaban partisipan. Pembuatan kategori berdasarkan kemiripan jawaban dan diskusi dengan asisten dan dosen peneliti. Pada studi 2 peneliti membuat alat ukur amanah berdasarkan indikator yang ditemukan pada penelitian pertama. Jumlah 
aitem yang dibuat sebanyak 40 aitem. Skala yang digunakan adalah model Likert dengan lima tipe pilihan $(1=$ "tidak sesuai"- " $5=$ sangat sesuai"). Misalkan, "Berkata sesuai dengan fakta"; "Dipercaya menjaga rahasia".

\section{Hasil}

\section{Studi 1}

Langkah pertama yang dilakukan setelah pengambilan data pada studi 1, yaitu mengorganisasikan data. Selanjutnya, membuat koding berdasarkan respon yang berasal dari pertanyaan terbuka tentang orang amanah. Jawaban partisipan dikelompokkan berdasarkan kesamaan atau kemiripan jawaban sehingga menjadi satu kategori. Hasil kategori kemudian diuji dan didiskusikan dengan peneliti lain apabila terjadi perbedaan dalam menetapkan jawaban respon pada kategori tertentu. Hasil akhir menunjukkan bahwa terdapat 13 kategori dengan batas akhir
0,7\% jumlah partisipan (lihat Tabel 1).

Berdasarkan hasil studi 1 kategori yang memiliki presentase paling tinggi menggambarkan orang amanah adalah dapat dipercaya $(24,5 \%)$, partisipan penelitian mengartikan amanah sebagai orang yang dapat dipercaya. Dapat dipercaya dapat diartikan sebagai keyakinan kepada orang (trustee) bahwa orang tersebut dapat melakukan tugas. Dapat dipercaya lebih pada aspek kognitif individu (trustor) kepada orang (trustee) berdasarkan pengalaman, informasi dan kualitas karakter individu. Beberapa contoh jawaban responden "orang yang benar-benar dapat dipercaya...", "seperti orang yang bisa dapat dipercayai untuk memegang amanah tersebut" dan "orang yang dapat dipercaya". Pada konteks ini amanah tidak dilihat sebagai emosi, tetapi cenderung kognitif atau disposisi kepada seseorang berdasarkan kualitas pribadi yang dipersepsikan kepadanya.

Kedua, bertanggung jawab (11,9\%). Bertanggung jawab merupakan karakter

Tabel 1.

Presentasi partisipan dalam kategori orang amanah

\begin{tabular}{clcc}
\hline No & \multicolumn{1}{c}{ Koding kategori } & Frekuensi & \% \\
\hline 1 & Dapat dipercaya & 109 & 24.5 \\
2 & Bertanggung jawab & 53 & 11.9 \\
3 & Menjaga kepercayaan & 46 & 10.4 \\
4 & Mampu melakukan tugas & 44 & 9.9 \\
5 & Jujur & 43 & 9.7 \\
6 & Menepati janji & 32 & 7.2 \\
7 & menyampaikan pesan dengan baik & 40 & 9.0 \\
8 & Menjaga rahasia & 26 & 5.9 \\
9 & Menjaga simpanan & 16 & 3.6 \\
10 & Menjaga titipan & 9 & 2.0 \\
11 & Baik & 5 & 1.1 \\
12 & Seperti Rasululloh & 4 & 0.9 \\
13 & Menjaga perkataan & 3 & 0.7 \\
14 & Lain & 14 & 3.2 \\
\hline & Total & 444 & 100 \\
\hline
\end{tabular}


positif yang memiliki arti menerima segala risiko atas tugas yang diberikan dan melaksanakan tugas sebaik-baiknya. Beberapa contoh jawaban responden berkaitan dengan kategori ini, yaitu: "orang yang dikatakan amanah itu adalah orang yang sangat bertanggung jawab atas amanah yang diberikan dan bertanggung jawab "orang yang peduli terhadap orang lain, jujur, bertanggung jawab" dan "jujur dalam situasi apapun..."

Ketiga, menjaga kepercayaan (10,4\%). Menjaga amanah merupakan kemampuan individu dalam mengerjakan amanah (tugas) dan menjaga amanah sehingga amanah dapat ditunaikan kepada yang berhak. Berdasarkan hasil penelitian ini ada dua jenis dalam menjaga amanah, pertama hal yang bersifat fisik, yang meliputi menjaga barang milik orang lain, seperti jawaban responden "yang mampu menjaga suatu titipan baik barang, jabatan, maupun nasehat"," orang yang bisa menjaga titipan.." dan psikologis (non fisik). Seperti jawaban responden "orang yang mampu menjaga kepercayaan orang lain", " yang bisa menjaga rahasia, sangat penting".

Secara umum hasil kategori pada studi 1 menunjukkan bahwa konsep amanah lebih dipahami pada konteks interpersonal. Amanah diartikan sebagai orang yang dapat dipercaya, bertanggung jawab, mampu menjaga kepercayaan (lihat Tabel 1). Hasil penelitian ini membuktikan pemahaman mahasiswa yang melekatkan amanah dalam konteks hubungan interpersonal manusia dan tidak secara langsung mengartikan amanah dalam konteks ibadah kepada Allah. Berdasarkan uraian tersebut amanah dapat diartikan pada dua hal, yaitu sebagai beban yang harus dilaksanakan, seperti melaksanakan tugas dan kedua amanah sebagai kualitas pribadi yang ditunjukkan dengan sifat dan perilaku yang positif, seperti bertanggung jawab, menjaga rahasia dan baik.

\section{Studi 2}

Pada studi 2 dilakukan konstruksi skala amanah berdasarkan hasil eksplorasi studi 1. Langkah-langkah dalam menyusun skala amanah, sebagai berikut: Pertama, identifikasi konstrak amanah. Konstrak amanah yang digunakan dalam penelitian ini adalah berdasarkan hasil temuan pada studi 1. Orang amanah dalam penelitian ini, didefinisikan sebagai individu yang memiliki karakter positif (dapat dipercaya, bertanggung jawab, jujur, dan lainnya) serta memiiliki kemampuan dalam melaksanakan tugas yang dibebankan. Jadi dapat disimpulkan bahwa ada dua aspek dalam amanah, yaitu karakter positif dan kemampuan melaksanakan tugas. Kedua, penskalaan dan penulisan aitem. Model penyusunan skala amanah dengan model Likert dengan lima tipe plihan (Sangat Sesuai, Sesuai, Cukup Sesuai, Kurang Sesuai, Tidak Sesuai) dengan penilaian dari 1 sampai 5. Langkah selanjutnya membuat blue print (lihat Tabel 2) dan membuat aitem berdasarkan aspek dan indikator yang berjumlah 40 aitem, yang terdiri dari aspek karakter positif sebanyak 23 aitem (57,5\%) dan aspek kemampuan melaksanakan tugas sebanyak 17 aitem (42,5\%). Distribusi aitem disesuaikan dengan jumlah frekuensi yang diperoleh pada studi 1.

\section{Review dan Uji coba}

Langkah selanjutnya adalah melakukan review terhadap aitem yang telah ditulis. Review dilakukan oleh dosen/peneliti yang dianggap berkompeten dalam memahami konsep amanah. Tujuannya dilakukan review untuk meningkatkan kualitas isi aitem, kesesuaian dengan blue print (validitas isi) serta untuk mengetahui tata bahasa dalam skala amanah. Selanjutnya dilakukan uji coba untuk mengeta- 
Tabel 2

Blue print skala amanah

\begin{tabular}{|c|c|c|c|c|}
\hline No & Aspek & Indikator & Jumlah Aitem & Bobot $(\%)$ \\
\hline \multirow[t]{5}{*}{1} & Karakter positif & Dapat dipercaya & & \\
\hline & & Bertanggung jawab & 23 & $57,5 \%$ \\
\hline & & Jujur & & \\
\hline & & Menepati janji & & \\
\hline & & Baik & & \\
\hline \multirow[t]{7}{*}{2} & Melaksanakan tugas & Mampu melakukan tugas & & $42,5 \%$ \\
\hline & & Menjaga kepercayaan & 17 & \\
\hline & & Menjaga rahasia & & \\
\hline & & Menjaga titipan & & \\
\hline & & Menjaga perkataan & & \\
\hline & & $\begin{array}{l}\text { Menyampaikan pesan } \\
\text { dengan baik }\end{array}$ & & \\
\hline & & Total & 40 & $100 \%$ \\
\hline
\end{tabular}

hui reliabilitas dan melihat daya diskriminasi aitem. Berdasarkan uji relibilitas dengan pendekatan konsistensi internal alpha diperoleh reliabilitas sebesar 0,92. Setelah dilakukan uji korelasi aitem-total terdapat tiga aitem yang gugur (nilai $\leq$ 0,30 ). Selanjutnya dilakukan analisis faktor eksplatori menggunakan 37 aitem. Tujuannya untuk mengetahui struktur atau komponen yang terbentuk pada konsep amanah.

\section{Analisis Faktor}

Analisis faktor dilakukan terhadap 37 aitem amanah. Analisis faktor yang digunakan adalah analisis faktor eksplaratori yang bertujuan untuk mengidentifikasi faktor-faktor yang terbentuk dalam suatu pengukuran (Steven, 2009). Sebelum melakukan apakah suatu data layak dilakukan analisis faktor, maka perlu dilakukan beberapa pengujian pendahuluan.

Kaiser-Meyer-Olkin Measure of Sampling Adequacy (KMO) bertujuan untuk melihat apakah data atau sampel adekuat untuk dilakukan analisis faktor. KMO bergerak dari 0 sampai 1 . Sementara hasil Bartlet's tes bertujuan untuk menilai apakah suatu variabel berkorelasi signifikan dengan variabel lain dengan kriteria $p<0,01$. Measures of sample of adecuacy (MSA) bertujuan untuk melihat korelasi antarvariabel dalam data penelitian. Analisis faktor dapat dilakukan jika korelasi antarvariabel lebih besar 0,5 (Hair, dkk, 2006). Hasil penelitian menunjukkan $\mathrm{KMO}=0,868$, $\chi 2(630, N=201)=3200,136, p=0,000$. Hasil menunjukkan semua variabel lebih besar dari 0,5. Hal tersebut menunjukkan bahwa semua variabel dapat diikutkan dalam analisis lanjutan. Dengan diterima semua uji pendahuluan, maka analisis faktor terhadap 37 variabel dapat dilakukan.

\section{Ekstraksi Faktor}

Ekstraksi faktor dilakukan dengan metode principal component analysis (PCA). Menurut Fabrigar, dkk., (1999) PCA merupakan metode yang cocok untuk mereduksi data. Hasil analisis faktor pada 37 variabel terbentuk 8 faktor. Penentuan ini berdasarkan pada nilai initial eigenvalues di atas 1, dan nilai total kumulatif varians sebesar 60\% (Hair, dkk., 2006). Pada faktor 1 terdiri dari 9 aitem dengan total varians sebesar $11,188 \%$. Hal ini berarti faktor 1 dapat menjelaskan 11,12\% konsep amanah. Faktor 2 terdiri dari 5 
aitem dengan varians sebesar $8,92 \%$, faktor 3 terdiri 5 aitem dengan varians sebesar $7,87 \%$, faktor 4 terdiri dari 5 aitem dengan varians sebesar $7,84 \%$, faktor 5 terdiri dari 4 aitem dengan varians sebesar 7,84\%, faktor 6 terdiri dari 4 aitem dengan varians sebesar 7,30\% faktor 7 terdiri dari 3 aitem dengan varians $6,30 \%$ dan faktor 8 terdiri dari 1 aitem dengan varians sebesar 3,70\%. Total kumulatif varians pada semua faktor sebesar $60,55 \%$.

Permasalahan yang muncul dalam pemberian label faktor adalah ketika faktor yang terbentuk banyak, seperti pada penelitian ini terbentuk 8 faktor. Ada beberapa faktor antara satu variabel dengan variabel yang tidak selaras sehingga kesulitan dalam pemberian label pada faktor. Oleh karena itu, peneliti mencoba melakukan ekstraksi faktor menjadi lebih kecil agar lebih mudah dalam memberi label faktor. Berdasarkan pada studi 1, aspek amanah terdiri dari 2 aspek. Selanjutnya, dilakukan perbandingan apakah konstrak amanah lebih baik dua atau tiga aspek. Akhirnya, peneliti memilih menjadi tiga aspek karena dari hasil penelitian lebih baik dalam menjelaskan varians konstrak amanah dan berdasarkan hasil penelitian Mayer, dkk (1995) tentang keterpecayaan (trustworthinnes) yang membagi menjadi tiga komponen, yaitu kemampuan, kebajikan, dan integritas.

Tabel 3

Rotasi faktor skala amanah

\begin{tabular}{clccc}
\hline \multirow{2}{*}{ No } & \multicolumn{1}{c}{ Variabel/aitem } & \multicolumn{3}{c}{ Faktor } \\
\cline { 2 - 5 } & & $\mathbf{1}$ & $\mathbf{2}$ & $\mathbf{3}$ \\
\hline 1 & Dipercaya menjaga rahasia & 0,746 & \\
2 & Berkata jujur & 0,656 & \\
3 & Menjaga kepercayaan dari orang lain & 0,624 & \\
4 & Saya sepenuhnya dapat dipercaya & 0,614 & \\
5 & Menepati janji & 0,611 & \\
6 & Berkata sesuai dengan fakta & 0,598 & \\
7 & Menjaga titipan seperti semula & 0,539 & & \\
8 & Menyampaikan pesan dengan baik & & 0,721 & \\
9 & Menyelesaikan tugas tepat waktu & & 0,611 & \\
10 & Mengerjakan sesuatu sampai tuntas & & 0,576 & \\
11 & Melaksanakan tugas yang diberikan & & 0,571 & \\
12 & Melaksanakan sholat waktu tepat waktu & & 0,570 & \\
13 & Mengerjakan sesuatu dengan serius & & 0,566 & \\
14 & Patuh pada aturan & & 0,561 & \\
15 & Serius menjacapai tujuan & & 0,539 & \\
16 & Mengerjakan pekerjaan sepenuh hati & & 0,521 & \\
17 & Melaksanakan ibadah sunnah secara rutin & & & 0,721 \\
18 & Teguh memegang prinsip & & & 0,685 \\
19 & Berusaha menghibur orang lain & & & 0,622 \\
20 & Peduli dengan orang lain & & & \\
21 & Berusaha menolong orang lain walaupun di waktu sibuk & & & \\
22 & Menjadi tempat berbagi (sharing) masalah teman & & & \\
23 & Bertindak sesuai hati nurani & & & \\
\hline
\end{tabular}

Ket: $\mathrm{N}=201$, aitem yang digunakan memiliki faktor loading $>0,50$. Sementara ada 14 aitem yang memiliki faktor loading $<0,5$, sehingga tidak diikutkan dalam penelitian. 
Setelah melakukan ekstraksi variabel menjadi tiga, maka langkah selanjutnya dilakukan rotasi faktor untuk meningkatkan dan memperjelas interpretasi variabel dengan menggunakan metode rotasi orthogonal dengan pendekatan varimax, yaitu berusaha memaksimalkan penyebaran faktor loading pada faktor dengan cara memilih faktor loading yang tinggi pada satu faktor (Field, 2009). Menurut Field, (2009) metode varimax merupakan pendekatan yang baik dalam memudahkan interpretasi faktor. Pada penelitian ini terdapat tiga faktor, yaitu faktor 1: integritas $(28,866 \%)$, yaitu kemampuan individu dalam memegang prinsip-prinsip universal, seperti keterbukaan, kepercayaan, menepati janji dan kejujuran. Melakukan tugas $(7,058 \%)$, yaitu kemampuan individu dalam melakukan atau menyelesaikan suatu pekerjaan dan kebajikan (benevolence), (5,699\%), yaitu keinginan individu untuk berbuat baik kepada orang lain, seperti peduli, ramah dan menghibur orang lain. Total kumulatif varians pada semua faktor sebesar $41,62 \%$.

\section{Diskusi}

Penelitian ini bertujuan untuk mengeksplorasi konsep amanah dalam pandangan kehidupan sehari-hari dan kedua membuat alat ukur amanah berdasarkan hasil studi 1. Berdasarkan hasil pada studi 1 diperoleh hasil bahwa orang yang amanah terdiri dari beberapa kategori (lihat Tabel 1), yaitu dapat dipercaya, bertanggung jawab, menjaga kepercayaan, jujur dan mampu melaksanakan tugas. Berdasarkan hasil ini dapat dijelaskan bahwa konsep amanah melekat pada orang yang menjadi target amanah. Artinya, orang dikatakan amanah adalah orang yang dapat dipercaya, memiliki karakter positif (bertanggung jawab, jujur, menjaga kepercayaan), dan melakukan tugas yang diberikan.

Konsep amanah cenderung arahnya kepada hubungan interpersonal (horizontal) antar manusia, walaupun ada beberapa subjek yang mengkaitkan amanah dengan kewajiban menjalankan agama, seperti melaksanakan perintah Allah atau Rasul. Padahal dalam konsep islam, konsep amanah sangat luas yang mencakupi urusan agama dan duniawai (Ibnu Katsir, 2013). Sementara dalam perspektif psikologi, amanah cenderung lebih dekat kepada kepercayaan (trust) dan keterpecayaan (trustworthiness). Namun perbedaannya, dalam islam konsep amanah tidak hanya berkaitan dengan hubungan interpersonal tetapi juga hubungan dengan Allah. Hal tersebut dibuktikan pada kategori melaksanakan tugas, terdapat jawaban partisipan yang menjawab melaksanan perintah Allah atau Rasul. Sementara pada konsep psikologi, kepercayaan dan keterpecayaan berada pada tataran hubungan interpersonal antarmanusia.

Berdasarkan hasil studi 1 dapat dijelaskan bahwa amanah merupakan konsep terletak pada dua hal, yaitu pembebanan tugas dan kualitas individu. Pertama, amanah didefinisikan sebagai beban tugas yang diberikan untuk dilaksanakan. Tugas ini dapat berasal dari manusia ataupun tugas agama (dari Allah atau Rasul). Setiap tugas yang diberikan adalah amanah, artinya tugas tersebut harus dilaksanakan sesuai dengan perintah. Apabila tugas tidak dilaksanakan akan memiliki konsekuensi, yaitu apabila dilaksanakan akan memperoleh imbalan dan apabila tidak dilaksanakan akan memperoleh sanksi. Konsep ini banyak dibahas dalam perspektif islam, amanah dapat diartikan tugas yang harus dilaksanakan individu, seperti yang ada 
dalam Al-Quran surat Al Ahzab ayat 72: "Sesungguhnya Kami telah mengemukakan amanat kepada langit, bumi dan gununggunung, maka semuanya enggan untuk memikul amanat itu dan mereka khawatir akan mengkhianatinya... dan surat $\mathrm{Al}$ Mukminun ayat 8" Dan orang-orang yang memelihara amanat-amanat (yang dipikulnya) dan janjinya". Pada kedua ayat tersebut dijelaskan bahwa amanah itu adalah beban tugas yang diberikan Allah atau manusia untuk dipikul atau dilaksanakan bagi yang menerima amanah tersebut.

Kedua, amanah dimaknai sebagai kualitas individu berarti amanah sebagai sifat baik yang harus dimiliki oleh setiap muslim, seperti bertanggung jawab, jujur, melaksanakan janji. Konsep ini mirip dengan konsep keterpecayaan (Mayer, dkk., 1995). Jika dilihat dari teori keterpecayaan oleh Mayer, dkk., (1995) kualitas individu layak dipercaya meliputi tiga, yaitu kemampuan (kompetensi), integritas dan kebajikan. Hasil penelitian ini relatif sama dengan penelitian sebelumnya yang meneliti tentang keterpecayaan pada individu, seperti keterpecayaan pada elit politik (Haryanto, dkk., 2015; Agung, dkk 2013), amanah pada orang tua dan saudara (Fitri \& Widyastuti, 2014, Munthe \& Widyastuti, 2014). Kesamaannya terletak bahwa konsep amanah dan keterpecayaan pada individu terletak pada karakter dan perilaku positif individu seperti kejujuran, tanggung jawab, konsistensi dan lainnya. Dalam perspektif islam, amanah merupakan salah satu sifat mulia yang harus dimiliki seorang muslim. Nabi bersabda: "Tidak (sempurna) iman seseorang yang tidak amanah." (HR. Ahmad). "Apabila suatu urusan diserahkan kepada orang yang bukan ahlinya, maka tunggulah datangnya kehancuran." (HR. Al-Bukhari). Dari hadis ini dapat disimpulkan bahwa amanah merupakan salah satu sifat yang sangat dijunjung tinggi dalam islam. Amanah dikaitkan dengan kemampuan individu dalam menyelesaikan, dan menjaga tugas hingga selesai. Misalkan, menjaga perkataan atau menyimpan rahasia.

Pada studi 2 membuat alat ukur amanah berdasarkan pada studi 1. Hasil penelitian menunjukkan bahwa konstrak amanah memiliki reliabilitas yang baik. Berdasarkan analisis faktor, konstrak amanah terdiri dari tiga faktor/komponen, yaitu integritas melaksanakan tugas dan kebajikan. Ada persamaan dan perbedaan konsep amanah dengan konsep Trustworthiness oleh Mayer, dkk., (1995). Persamaannya adalah kedua konsep tersebut berdasarkan pada trustee khususnya karakter positif individual (integritas dan kebajikan). Amanah dan keterpecayaan (trustworthiness) menjadi disposisi terhadap kepercayaan, seperti jujur, kompetensi, integritas, kebajikan (Mayer, dkk., 1995; McKnight. dkk., 1998). Perbedaannya adalah pada aspek kemampuan (ability). Pada konsep keterpecayaan (trustworthiness), aspek kemampuan (ability) diartikan sebagai suatu skill, kompetensi yang diperlukan untuk menyelesaikan suatu pekerjaan, sementara pada konsep amanah dinamakan faktor telah melaksanakan tugas. Individu dikatakan amanah jika ia dapat meyelesaikan tugas yang diberikan, artinya dalam melaksanakan tugas tidak hanya dibutuhkan kemampuan, tetapi juga komitmen dan konsistensi.

Akhirnya, amanah bukanlah emosi tetapi kognisi, sikap dan perilaku atau disposisi terhadap individu berdasarkan persepsi kualitas individu. Amanah yang dipahami partisipan cenderung lebih ke arah hubungan interpersonal. Faktor integritas (seperti jujur) menjadi sifat atau perilaku yang dominan dalam menjelaskan konsep amanah. Beberapa keterbatasan dalam penelitian. Pertama, jumlah 
dan variasi partisipan. Kedua, belum maksimalnya penelitian terutama dalam mengkonstruksi konstrak amanah. Ketiga, keterbatasan penelitian tentang amanah sehingga kurang dapat mengeksplorasi amanah dari perspektif islam.

\section{Kesimpulan}

Amanah merupakan konsep islam yang sudah sering digunakan dalam konteks masyarakat Indonesia. Berdasarkan hasil studi 1 menunjukkan bahwa prototipe orang amanah adalah orang yang memiliki karakter positif, seperti dapat dipercaya, bertanggung jawab dan jujur, dan orang yang mampu melaksanakan tugas yang diberikan. Sementara pada studi 2 menghasilkan 3 faktor atau komponen dalam skala amanah yatu integritas, melaksanakan tugas dan kebajikan.

\section{Saran}

Penelitian selanjutnya seharusnya mengeksplorasi dan menguji validitas konstrak skala amanah sehingga memperoleh instrumen yang lebih valid. Selain itu, perlu fokus pada aspek tertentu misalkan amanah dalam hubungan interpersonal, amanah dalam hubungan dengan Allah atau amanah sebagai kepribadian (state or trait of amanah) sehingga dapat mengurangi overlap dengan variabel lain, seperti religiusitas, kepercayaan, keterpecayaan, dan kejujuran.

\section{Kepustakaan}

Agung, I.M., Masyhuri \& Hidayat. (2013). Dinamika ketidakpercayaan terhadap politisi: Suatu pendekatan psikologi indigenous. Jurnal Psikologi, 9(1) 25-30.

Amirin, T.M (2007). Kepemimpinan yang amanah. Dinamika Pendidikan, 1(14), 111.
Allemand, M., Amberg, I., Daniel Zimprich, D \& Fincham, F.D. (2007) The role of trait forgiveness and relationship satisfaction in episodic forgiveness. Journal of Social and Clinical Psychology, 26(2), 199-217.

Bohnet, I \& Baytelman, Y. (2007). Institutions and trust implications for preferences, beliefs and behavior. Rationality And Society, 19(1) 99-135.

Badan Pengembangan dan Pembinaan Bahasa Kemdikbud. (2014). Kamus Besar Bahasa Indonesa (KBBI). Diunduh dari http://kbbi.web.id/ pada tanggal 14 November 2014.

Colquitt, J.A, Scott,B .A and LePine, J. A. (2007).Trust, Trustworthiness, and Trust Propensity: A Meta-Analytic Test of Their Unique Relationships With Risk Taking and Job Performance, Journal of Applied Psychology, 92 (4), 909-927.

Fabrigar, L.R., Wegener, D.T., MacCallum, R.C \& Erin J. Strahan, E.J. (1999). Evaluating the use of exploratory factor analysis in psychological research. Psychological Methods, 4(3), 272-299.

Field, A. (2009). Discovering statistic using SPSS. Third Edition. London: Sage Publication.

Fitryani, E (2014). Profil Pemimpin Amanah Sudut pandang mahasiswa: Pendekatan psikologi Indigenous. Naskah tidak dipublikasikan. Fakultas Psikologi UIN Suska Riau.

Fitri, A.R. \& Widyastuti, A. (2014). Orang tua yang amanah: Tinjauan psikologi indijinus. Naskah tidak dipublikasikan. Fakultas Psikologi UIN Suska Riau.

Fehr, B. \& Russell, J. A. (1991). The concept of love viewed form a prototype perspective. Journal of Personality and Social Psychology, 60, 425-458. 
Frei, J.R \& Shaver, P.R. (2002). Respect in close relationship: Prototype definition, self-report assessment, and initial correlate. Personal Relationship, 9, 121139

Furr, R.M. (2011). Scale construction and psychometrics for social and personality psychology. SAGE Publication: London.

Hair, J., Blak, W.C., Babin, B.J., Andersen, R.E., \& Ratham, R.L. (2006). Multivariate data analysis. Sixth edition. New Jersey: Pearson Prentice Hall.

Hamka. (1990). Tasauf modern. Jakarta: Pustaka Panji Mas.

Haryanto, H.C, Rahmania, T., Mubarok, A.R., Dopo, A.B., Fauzi \& Fajri, H.E. (2015). Bagaimanakah persepsi keterpercayaan masyarakat terhadap elit politik? Jurnal Psikologi, 42(3), 243-258.

Ibnu Katsir. (2013). Tafsir Ibnu Katsir. Jakarta: Pustaka Imam Syafii.

Langdon, S.W. (2007). Conceptualizations of respect: Qualitative and quantitative evidence of four (five) themes. The Journal of Psychology, 141(5), 469484.

Lee, G \& Schallert, D.L. (2008). Constructing trust between teacher and students through feedback and revision cycles in an EFL writing classroom. Written Communication, 25(4), 506-537

Lestari, S, Faturochman, \& Kim, U. (2010). Trust in parent-child relationship among undergraduate students: Indigenous psychological analysis. Jurnal Psikologi, 37(2), 140-152.

Lewicki, R.J., Mcallister, D.J, \& Bies, R,.J (1998). Trust and distrust: New relationships and realities. Academy of Management Review , 23(3),438-458.

Mark N.K., Saunders, M.N.K., \& Thornhill, A. (2004). Trust and mistrust in organizations: An exploration using an organizational justice framework. European Journal Of Work And Organizational Psychology, 13(4), 493-515.

Mayer, R. C., Davis, J.H., \& Schoorman, F. D. (1995). An integrative model of organizational trust. The Academy of Management Review, 20(3), 709-734. doi: $10.2307 / 258792$

McCullough, M.E., Everett L. Worthington, E.L., \& C. Rachal. C. (1997). Interpersonal forgiving close relationships. Journal of Personality and Social Psychology . 73(2), 321-336.

McKnight, D.H., Larry L Cummings, L.L., \& Chervany, N.L. (1998). Initial trust formation in new organizational relationships. The Academy of Management Review, 23(3), 473-490.

Miller, P.J.E \& Rempel, J.K. (2004). Trust and partner-enhancing attributions in close relationships. Personality And Social Psychology Bulletin, 30(6), 695705.

Munthe, R.A \& Widyastuti, A. (2014). Saudara yang amanah: Tinjauan psikologi indijinus. Naskah tidak dipublikasikan. Fakultas Psikologi UIN Suska Riau.

Pamuji, J \& Zulaifah E . (2008). Sulitnya Menjaga Amanah Pada Anggota DPRD Daerah Istimewa Yogyakarta diunduh dari http://psychology.uii. ac.id/images/stories/jadwal_kuliah /naskah-publikasi-02320213.pdf. tanggal 26 maret 2014 .

Pulungan, S. (2006). Wawasan Tentang Amanah dalam Al-Quran. (Disertasi tidak dipublikasikan). UIN Syarif Hidayatullah.

Rohman, F.(2011). Konsep Metode dan Penanaman Nilai Amanah dalam AlQuran. (Tesis tidak dipublikasikan). Program Studi Pendidikan Islam UIN Sunan Kalijaga. 
Rousseau, D. M., Sitkin, S. B., Burt, R., dan Camerer, C. (1998). Not so different after all: A cross-discipline view of trust. Academy of Management Review. 23(3), 393-404.

Suprihatiningrum, J \& Premono, S. (2012). Student perception against the concept of fathonah, amanah, shidiq, and tabligh (fast) and its relation to the readiness to be a professional and characterized teacher. Conference Proceeding. Annual International Conference On Islamic Studies" (Aicis) Xii/2012 Di Surabaya, 5-8 November.

Stevens, (2009). Applied multivariate statistic for the social science. Fith edition. New York: Routledge Taylor \& Francis Group New York.

Tanis, M \& Postmes, T. (2005). A social identity approach to trust: Interpersonal perception, group membership and trusting behavior. European Journal of Social Psychology, 35, 413-424.

Tranajaya, A. (2011). Hubungan amanah dan motivasi kerja dengan etos kerja kader Hidayatulloh. Tesis tidak dipublikasikan. Fakultas Ilmu Politik Universitas Indonesia.

Wieselquist, J., Rusbult, C.,E \& Foster, C.A., \& Christopher R. Agnew, C.R. (1999). Commitment, pro-relationship behavior, and trust in close relationships. Journal of Personality and Social Psychology, 77(5), 942-966.

Wahyuni, S (2014). Ibu yang amanah di mata remaja: Pendekatan psikologi indigenous. Naskah tidak dipublikasikan. Fak Psikologi UIN Suska Riau.

Yamagishi, T. \& Yamagishi, M. (1994). Trust and comitment in the United States and Japan. Motivation and Emotion. 18(2), 129-166. 